\title{
Kebijakan Indonesia Dalam Penanganan Peredaran Narkoba Di Segitiga Emas Asean Pada Masa Pandemi Covid-19
}

\author{
Muhammad Khusna Bayu Hardianto \\ Departemen Hubungan Internasional Universitas Indonesia \\ (m.khusna@ui.ac.id)
}

\begin{abstract}
The COVID-19 pandemic affects almost every aspects of human life globally. Naturally, various forms of adaptation were applied. So as the illicit drug trafficking that also affected by the pandemic. The disclosure of drug smuggling cases in Southeast Asia proves that drug syndicates have adapted to the global pandemic situation with its restrictions. The golden triangle is known as one of the source area of drug trafficking and production in Southeast Asia and also the world. The area has become main concern of ASEAN for decades. Various mechanisms at the regional and sub-regional levels has been applied to tackle the problem. Indonesia, as a transit country and the largest market in the region, annually dismantle illicit drug trafficking cases from the golden triangle area. During the first 2 years of the pandemic, numbers of cases have been revealed. Using the theory of Republican Liberalism, this article describes Indonesia's policy in anti-drug cooperation to handle the golden triangle. This research was conducted using qualitative method. Data collected through literature studies of journals, documents and reports from relevant agencies beside qualitative interviews with competent source persons. The result indicates that Indonesia is not prioritize the Golden Triangle in its foreign policy at the regional level. The existing findings indicate that there are several limitations, especially at the domestic level, so that the government's point of view is still focused on the drug problem in the country. This article also found that although the pandemic complicates the movement, it has been successfully adapted by international and local drug syndicates.
\end{abstract}

Keywords: pandemic, foreign policy, golden triangle, Indonesia, narcotic drugs. 


\begin{abstract}
Abstrak
Pandemi COVID-19 berdampak luas di hampir seluruh aspek kehidupan manusia. Secara alamiah, berbagai bentuk adaptasi diterapkan. Begitu pula dengan peredaran gelap narkoba ${ }^{1}$ yang juga merasakan dampak pandemi. Meski demikian, pengungkapan kasus penyelundupan narkoba di Asia Tenggara membuktikan bahwa sindikat telah beradaptasi terhadap situasi pandemi global dengan segala pembatasannya. Kawasan Segitiga Emas dikenal sebagai salah satu sumber permasalahan produksi dan peredaran narkoba di Asia Tenggara dan juga dunia. Kawasan tersebut telah menjadi perhatian utama seluruh negara anggota ASEAN selama puluhan tahun. ASEAN menangani kejahatan narkoba melalui berbagai macam mekanisme kerja sama di tingkat regional dan sub regional. Indonesia, sebagai negara transit dan pasar terbesar di Asia Tenggara, setiap tahunnya mengungkap kasus peredaran gelap narkoba dari kawasan segitiga emas. Selama kurang dari 2 tahun pertama masa pandemi, telah terungkap sejumlah kasus peredaran narkoba. Dengan menggunakan teori Republican Liberalism, artikel ini menjelaskan tentang kebijakan Indonesia dalam penanganan narkoba di kawasan segitiga emas. Penelitian dilakukan dengan menggunakan metode kualitatif. Teknik pengumpulan data melalui studi literatur terhadap jurnal, dokumen dan laporan dari instansi terkait serta wawancara kualitatif dari narasumber yang kompeten. Hasil penelitian ini menunjukkan bahwa Indonesia belum menempatkan kerja sama penanganan narkoba di Segitiga Emas sebagai prioritas dalam kebijakan luar negerinya di tingkat regional. Artikel ini juga mengungkapkan bahwa pandemi meskipun mempersulit gerakan, namun berhasil diadaptasi oleh sindikat narkoba baik internasional maupun lokal. Temuan yang ada menunjukkan bahwa terdapat beberapa keterbatasan, utamanya pada level domestik, sehingga sudut pandang pemerintah masih berfokus pada permasalahan narkoba di dalam negeri.
\end{abstract}

Kata kunci: Indonesia, pandemi, kebijakan luar negeri, narkoba, segitiga emas

\footnotetext{
${ }^{1}$ Istilah narkoba merujuk pada narkotika dan obat-obatan, sedangkan narkotika adalah zat atau obat baik yang bersifat alamiah, sintetis, maupun semi sintetis yang menimbulkan efek penurunan kesadaran, halusinasi, serta daya rangsang. Sumber: Pengertian Narkoba (Narkotika dan Obat-obatan) https://bnn.go.id/pengertian-narkobadan-bahaya-narkoba-bagi-kesehatan/
} 


\section{Pendahuluan}

Pandemi COVID-19 yang terjadi sejak akhir tahun 2019 di seluruh dunia memberikan dampak yang sangat luas. Tidak hanya terbatas pada aspek kesehatan, akan tetapi juga politik, ekonomi dan sosial merasakan dampaknya. Berbagai aspek kehidupan global merespons dengan berbagai cara untuk beradaptasi. Begitu pula dengan pola peredaran narkoba yang juga mengalami gangguan dari rantai pasokan bahan baku, produksi hingga ke pengedar kelas kecil di jalanan.(Gomis, 2020) Tidak hanya negara yang melakukan adaptasi terhadap situasi pandemi global, jaringan sindikat kejahatan transnasional juga beradaptasi untuk mempertahankan kelangsungan aktivitas ilegalnya.

Pandemi COVID-19 sebenarnya bukanlah peristiwa global yang pertama kali membawa dampak besar dalam waktu relatif singkat bagi peredaran narkoba. Sepanjang sejarah, setidaknya dalam 25 tahun terakhir sebelum pandemi COVID19, terdapat 5 peristiwa yang secara signifikan menjadi gangguan bagi peredaran narkoba global.(Eligh, 2020) Pada tahun 1995 terjadi kelangkaan sabu di Amerika Serikat yang disebabkan kebijakan pembatasan Efedrin secara tibatiba dan mengakibatkan meningkatnya harga jual sabu di pasaran hingga mencapai
3 kali lipat, sedangkan kemurniannya menurun drastis. Saat itu sindikat segera beradaptasi dengan cara mencari bahan pengganti Efedrin. Pelarangan opium oleh rezim Taliban di Afghanistan tahun 2000 juga mengakibatkan penurunan pasokan heroin global secara drastis. Tidak seperti sabu yang merupakan narkoba sintetis dan dapat segera dicari bahan penggantinya, opium yang merupakan narkoba alami berasal dari tumbuhan membutuhkan waktu yang relatif lama untuk penyediaannya. Sindikat kemudian memilih beradaptasi dengan cara memenuhi permintaan heroin dengan mengambil opium dari kawasan segitiga emas di Myanmar. Wabah Severe Acute Respiratory Syndrome (SARS) yang merebak tahun 2003 meskipun bukan pandemi global, akan tetapi memiliki pengaruh bagi peredaran narkoba khususnya di wilayah Tiongkok, terutama di Guangdong dan Hong Kong. Terdapat penelitian yang menyatakan bahwa permintaan dan penyalahgunaan narkoba lokal menurun sejak awal wabah SARS menyebar, akan tetapi segera kembali normal dalam hitungan bulan.

Krisis ekonomi global tahun 2008 juga disebut sebagai salah satu peristiwa yang berdampak pada peredaran narkoba. Berdasarkan penelitian di beberapa negara di Eropa, permintaan dan penyalahgunaan 
narkoba secara umum menurun. Pada tahun 2010 penyakit jamur tanaman opium melanda Afghanistan dan menggagalkan hingga setengah dari jumlah panen opium tahunan. Kelangkaan opium ini berdampak lebih jauh dengan adanya ketidakpastian tingkat kemurnian dan peningkatan harga yang memicu tren pemalsuan heroin, penggunaan jarum suntik bekas, hingga meningkatnya risiko overdosis. Dalam setiap kasus, pasar dan sindikat beradaptasi terhadap situasi yang ada dan mencari cara untuk bertahan.

Secara logis, sindikat yang berhasil bertahan dalam krisis-krisis tersebut dapat tumbuh dan berkembang menjadi lebih kuat dan lebih siap dalam menghadapi krisiskrisis selanjutnya di masa depan. Akan tetapi, prediksi terhadap bagaimana pasar narkoba merespons situasi pandemi tidak dapat serta merta dilakukan hanya dengan melihat pengalaman masa lalu.(Giommoni, 2020) Terdapat faktor-faktor yang juga berperan dalam melihat bagaimana pasar narkoba beradaptasi terhadap situasi yang ada.

Selama ini perdagangan narkoba dilakukan secara tersembunyi dengan memanfaatkan celah-celah di antara arus

\footnotetext{
2 Istilah pasar narkoba menurut PBB berkaitan dengan sistem ekonomi di mana para aktor berinteraksi dalam produksi (budidaya narkotika alami dan pembuatan narkotika sintetis), penjualan,
}

perdagangan barang dan jasa di seluruh dunia. Menurut PBB, pasar narkoba ${ }^{2}$ bergantung pada berjalannya kegiatan ekonomi legal.(UNODC, 2021) Oleh karena itu, perubahan besar pada aspek sosial ekonomi global yang terjadi selama pandemi COVID-19 memberikan dampak yang sangat besar bagi peredaran narkoba. Penutupan akses baik jalur darat, laut maupun udara, pembatasan mobilitas dan aktivitas sosial berimbas secara langsung pada peredaran dan pasar narkoba. Berbagai perubahan perilaku dalam menghadapi pandemi menjadi faktor utama perubahan pola peredaran narkoba. Perubahan pola ini merupakan bentuk adaptasi baik sindikat maupun pasar narkoba untuk tetap menjalankan operasinya.

Peredaran narkoba di kawasan Asia Tenggara di masa pandemi COVID-19 tetap meningkat. Meskipun pandemi ini membatasi lalu lintas orang dan barang antar negara bahkan memperlambat pertumbuhan ekonomi di Asia Timur dan Tenggara, data menunjukkan bahwa produksi dan distribusi narkoba masih tetap berjalan. Apabila dibandingkan antara tahun 2019 dan 2020, terdapat peningkatan

dan pembelian narkoba. Pasar narkoba biasanya dikendalikan oleh dinamika permintaan dan pasokan. (UNODC, World Drug Report 2015) 
penyitaan narkoba sebesar $20 \% .^{3}$ Sindikat peredaran narkoba beradaptasi dengan cara mencari jalur-jalur baru terutama melalui laut, di antaranya Laut Andaman dan Selat Malaka. Sindikat juga disebut tetap mengembangkan peredaran di kawasan Segitiga Emas wilayah Myanmar dan menjaga stabilitas pasokan bahan kimia melalui celah-celah pembatasan perbatasan antar negara.

Begitu pula di Indonesia, berdasarkan data dari Badan Narkotika Nasional (BNN), di awal masa pandemi tidak terdapat perbedaan signifikan. Jumlah kasus masih tinggi, bahkan terdapat peningkatan terutama pengungkapan kasus narkoba sintetis. Selama pandemi juga terdapat peningkatan jumlah barang bukti yang disita pada beberapa jenis narkoba, baik narkoba alami maupun sintetis, meskipun sitaan methamphetamine dan ekstasi menurun.
Tabel 1. Jumlah Kasus Berdasarkan Jenis Narkoba

\begin{tabular}{|c|l|l|l|l|l|}
\hline Tahun & Cannabis & Meth & Ecstasy & $\begin{array}{l}\text { Synthetic } \\
\text { Cannabinoid }\end{array}$ & $\begin{array}{c}\text { Gorilla } \\
\text { Tobacco }\end{array}$ \\
\hline 2018 & 3.794 & 34.751 & 1.528 & $\begin{array}{l}\text { Tidak ada } \\
\text { data } \\
\text { (digolongkan } \\
\text { sebagai } \\
\text { NPS }^{4} \text { ) }\end{array}$ & 208 \\
\hline 2019 & 3.552 & 33.442 & 1.068 & 154 & 153 \\
\hline 2020 & 2.294 & 34.163 & 1.146 & 293 & 297 \\
\hline
\end{tabular}

Sumber: Indonesia Drug Report, BNN

Tabel 2. Jumlah Barang Bukti

\begin{tabular}{|c|l|l|l|l|c|}
\hline Tahun & Cannabis & Meth & \multicolumn{1}{|c|}{ Ecstasy } & $\begin{array}{c}\text { Synthetic } \\
\text { Cannabinoid }\end{array}$ & $\begin{array}{c}\text { Gorilla } \\
\text { Tobacco }\end{array}$ \\
\hline 2018 & $\begin{array}{l}75,30 \\
\text { ton }\end{array}$ & $\begin{array}{l}8,23 \\
\text { ton }\end{array}$ & $\begin{array}{l}2.314,29 \mathrm{gr} \\
1,59 \text { juta tablet }\end{array}$ & $\begin{array}{l}\text { Tidak ada data } \\
\text { (digolongkan } \\
\text { sebagai NPS) }\end{array}$ & $5,38 \mathrm{~kg}$ \\
\hline 2019 & $\begin{array}{l}11,47 \\
\text { ton }\end{array}$ & $\begin{array}{l}17,92 \\
\text { ton }\end{array}$ & $\begin{array}{l}142,72 \mathrm{~kg} \\
1,5 \mathrm{juta} \text { tablet }\end{array}$ & $17,53 \mathrm{~kg}$ & $12,92 \mathrm{~kg}$ \\
\hline 2020 & $\begin{array}{l}53,79 \\
\text { ton }\end{array}$ & $\begin{array}{l}8,79 \\
\text { ton }\end{array}$ & $\begin{array}{l}2,049.87 \mathrm{gr} \\
1,618,068.86 \\
\text { tablet }\end{array}$ & $154,92 \mathrm{~kg}$ & $101,72 \mathrm{~kg}$ \\
\hline
\end{tabular}

Sumber: Indonesia Drug Report, BNN

Pembatasan lalu lintas di Indonesia dan negara tetangga selama pandemi COVID-19 hanya berdampak sementara. Penyelundupan antar negara kembali berjalan normal beberapa saat setelah dibukanya kembali “lockdown". Pada tahun 2020, Polri menyita 1,2 ton methamphetamine kristal (sabu) dari sindikat narkoba Iran. ${ }^{5}$ Selama beberapa tahun terakhir tidak pernah ditemukan sindikat Iran sebagai pemasok methamphetamine ke Indonesia. Selama ini

\footnotetext{
${ }^{3}$ Methamphetamine Trafficking Has Surged in East and Southeast Asia, Despite COVID-19. 22 Juni 2021. $\quad$ https://indonesia.un.org/en/132545methamphetamine-trafficking-has-surged-east-andsoutheast-asia-despite-covid-19

4 New Psychoactive Substances (NPS)/Zat Psikoaktif Baru adalah "zat-zat yang disalahgunakan, baik dalam bentuk murni maupun sediaan, yang tidak/belum diatur oleh Konvensi Tunggal PBB 1961, atau Konvensi PBB tentang Zat
}

Psikotropika 1971, akan tetapi dapat mengakibatkan ancaman kesehatan masyarakat". UNODC Early Warning Advisory on New Psychoactive Substances https://www.unodc.org/LSS/Page/NPS

5 Kapolri Hadiri Pemusnahan 1,2 Ton Sabu dan 35.000 Ekstasi dengan Modus Impor Kurma. 2 Juli 2020.

https://tribratanews.polri.go.id/read/833/39/kapolrihadiri-pemusnahan-12-ton-sabu-dan-35000-ekstasidengan-modus-impor-kurma-1593670049 
methamphetamine yang diselundupkan ke Indonesia berasal dari kawasan Segitiga Emas.

Di sisi lain, pandemi COVID-19 telah mengakibatkan banyak orang kehilangan pendapatan. COVID-19 memiliki dampak sosial-ekonomi antara lain mengakibatkan 100 juta orang mengalami kemiskinan ekstrem, dan 255 juta orang kehilangan pekerjaan. ${ }^{6}$ Selain itu, PBB juga mengungkapkan adanya peningkatan signifikan secara global gangguan kondisi kesehatan mental. Faktor-faktor tersebut menjadi pemicu meningkatnya penyalahgunaan narkoba.

Indonesia merupakan negara pasar sekaligus negara transit bagi peredaran narkoba di Asia Tenggara. Setidaknya ada tiga faktor yang mempengaruhi situasi peredaran gelap narkotika di Indonesia, yaitu ekonomi, geografi dan demografi. Faktor ekonomi, antara lain disparitas harga antara negara sumber dan negara pasar, tingginya angka permintaan, dan adanya kesenjangan pendapatan. Faktor geografi Indonesia sebagai negara kepulauan dengan 17.508 pulau dan $85.000 \mathrm{~km}$ panjang garis pantai, serta 39 pelabuhan laut internasional dan 17 bandar udara internasional memiliki pengaruh terhadap peredaran dan penyelundupan narkoba. Faktor demografi jumlah penduduk Indonesia yang mencapai lebih dari 260 juta jiwa memiliki potensi menjadi pasar narkoba.(Kanato et al., 2018)

Pentingnya melihat isu narkoba sebagai ancaman bagi Indonesia terlihat dari laporan-laporan tahunan baik yang dikeluarkan oleh Badan Narkotika Nasional (BNN) maupun laporan ASEAN Drug Monitoring Report yang berisi perkembangan isu di kawasan. Sepanjang tahun 2017, 51.464 kasus narkotika dengan 64.526 tersangka telah berhasil diungkap oleh BNN dan Polri. Sebanyak 151,5 ton ganja, 3,8 ton crystalline methamphetamine (sabu), dan 3 juta pil ekstasi telah disita.(Kanato et al., 2018) Selama tahun 2018 jumlah kasus tindak pidana narkotika yang berhasil diungkap oleh BNN dan Polri sebanyak 45.905 kasus dengan total tersangka sebanyak 59.533 orang. Dari jumlah kasus tersebut, 34.751 kasus di antaranya berkaitan dengan methamphetamine.

Methamphetamine sebagai jenis narkotika yang paling banyak disalahgunakan dan disita di Indonesia berasal dari Tiongkok dan wilayah Segitiga

\footnotetext{
${ }^{6}$ COVID pandemic fuelling major increase in drug use worldwide: UN report. 24 Juni 2021. https://news.un.org/en/story/2021/06/1094672
} 
Emas ASEAN. Secara geografis Segitiga Emas adalah sebutan bagi sebuah wilayah di antara sungai Mekong dan Sungai Mae Sai yang merupakan bagian dari wilayah negara Myanmar, Laos dan Thailand yang disebut sebagai sumber produksi dan peredaran gelap narkotika di Asia Tenggara. United Nation Office for Drugs and Crime (UNODC) dalam laporannya menyebutkan, pada tahun 1990an wilayah Segitiga Emas mampu memproduksi 1.800 hingga 2.000 ton opium dan 150 ton heroin per tahun dan diedarkan ke seluruh dunia.(Lijun, 2006)

Permasalahan produksi dan peredaran narkoba di Asia Tenggara seringkali terkait dengan kawasan segitiga emas. Kawasan ini disebut-sebut sebagai sumber terbesar peredaran narkotika di Asia Tenggara dan juga menjadi salah satu pusat peredaran dan produksi narkoba. Segitiga emas ini merupakan sebuah kawasan seluas $950.000 \mathrm{~km} 2$ yang meliputi wilayah negara Myanmar, Laos, dan Thailand.(Kanato et al., 2018)

\footnotetext{
7 The Drug Epidemic in Asia by Asyura Salleh 30 September 2020
} drug-trafficking-in-asia-golden-triangle 21 Juni 2021

\section{Gambar 1. Kawasan Segitiga Emas}

Sumber: kontinentalist.com ${ }^{7}$

Kawasan segitiga emas semula dikenal sebagai salah satu kawasan budidaya opium dunia selain kawasan bulan sabit emas (golden crescent) di wilayah Timur Tengah. Namun dalam perkembangannya, dengan ditemukannya narkotika sintetis dan berkembangnya zatzat baru, kawasan segitiga emas mulai memproduksi metamphetamine.

Dalam beberapa tahun terakhir, setidaknya terdapat dua pengungkapan kasus terbesar penyelundupan methamphetamine di tahun 2018 yang dapat menggambarkan bahwa Indonesia menjadi titik penting dalam peredaran gelap narkoba di kawasan. Kasus penyelundupan 
1,6 ton methamphetamine yang digagalkan Polri dan 1 ton methamphetamine yang digagalkan oleh tim gabungan BNN, Bea Cukai dan TNI AL keduanya menggunakan kapal laut dan menggunakan jalur perairan Kepulauan Riau. Dari seluruh kasus yang diungkap, di tahun 2018 terdapat 83 jaringan sindikat narkoba yang teridentifikasi beroperasi di Indonesia, sedangkan pada tahun 2017 terdapat sebanyak 99 jaringan. Banyaknya jumlah kasus dan jumlah barang bukti yang diungkap merupakan hasil kerja sama antar lembaga antara lain BNN, TNI, Polri dan Bea Cukai. Salah satu bukti sinergi yang dilakukan, yaitu pengungkapan kasus 1,037 ton methamphetamine di perairan Batam, pada bulan Februari 2018.

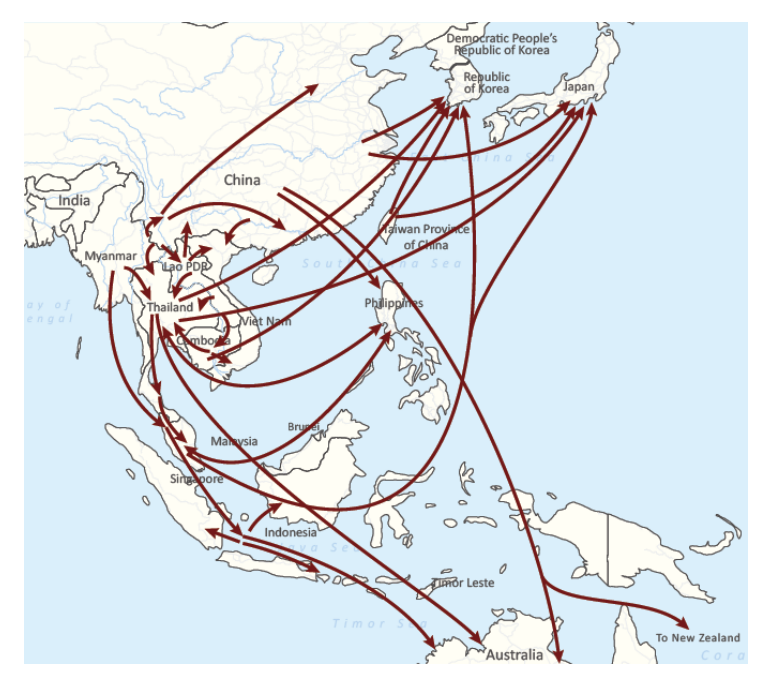

\section{Gambar 2. Jalur Peredaran Sabu} (crystalline methamphetamine) di Asia Tenggara dan Sekitarnya. Sumber:

\footnotetext{
${ }^{8}$ Synthetic Drugs in East and South-East Asia Trends and Patterns of Amphetamine-type Stimulants and
}

Laporan UN Global SMART Programme $2019^{8}$

Pada tahun 2014, BNN bekerja sama dengan Pusat Penelitian Kesehatan UI telah melakukan survey dengan hasil yaitu prevalensi penyalahgunaan narkoba secara umum pada kelompok usia 10-59 tahun sebesar 2,18\%. Hasil survei tersebut juga digunakan untuk menghitung proyeksi angka prevalensi penyalahgunaan narkoba secara umum pada tahun 2016 sebesar $2,21 \%$ atau setara dengan 4.173 .633 orang. Pada tahun 2016, BNN dan Pusat Penelitian Kesehatan UI telah melakukan "Survei Penyalahgunaan dan Peredaran Gelap Narkoba pada Kelompok Pelajar dan Mahasiswa" dengan hasil angka prevalensi pelajar yang pernah memakai narkoba sebesar 3,8\% dan memakai setahun terakhir sebesar 1,9\%. (Badan Narkotika Nasional, 2017)

Dilihat dari faktor demografi, Indonesia merupakan pasar narkoba yang besar di Asia Tenggara. Pandangan mengenai besarnya ancaman narkoba bagi Indonesia diperkuat dengan hasil survei yang mengindikasikan besarnya jumlah penduduk berusia produktif termasuk kalangan pelajar yang rentan bahkan sudah

New Psychoactive Substances, A Report from the Global SMART Programme 2019 
terpapar narkoba, sedangkan diprediksi bahwa antara tahun 2020 hingga 2030 Indonesia akan memperoleh "bonus demografi" penduduk. Masyarakat berusia produktif akan berjumlah lebih banyak daripada usia tidak produktif. (Badan Narkotika Nasional, 2018)

Penyalahgunaan dan peredaran gelap narkoba di Indonesia tidak lepas dari situasi peredaran narkoba di dunia dan terutama di kawasan Asia Tenggara. Sasaran peredaran narkoba tidak lagi terbatas di lingkungan seperti tempat hiburan malam, tetapi sudah merambah ke pemukiman, sekolah, dan kampus.(Kementrian Kesehatan RI, 2017) Berbagai jenis narkoba kini juga diperjualbelikan melalui internet (UN, 2015), pemanfaatan teknologi ini memudahkan peredarannya termasuk di Indonesia.

Baik di lingkup global, regional maupun nasional di berbagai negara, narkoba merupakan salah satu ancaman keamanan non-tradisional. Sekretaris Jenderal PBB pada tahun 2008 telah menetapkan tujuh ancaman maritim, salah satunya adalah penyelundupan narkoba. (Sudirman, 2020)

Dengan mempertimbangkan situasi ancaman narkoba yang dihadapi serta posisi
Indonesia yang di lingkup ASEAN sering dipandang sebagai leading actor melalui berbagai inisiatifnya, seharusnya Indonesia dapat berperan aktif dan menunjukkan upaya konkret dalam mendukung kerja sama penanggulangan narkoba di wilayah Segitiga Emas. Namun dalam perkembangannya, Indonesia tidak terlihat berperan aktif dalam mekanisme kerjasama terkait segitiga emas. Artikel ini akan menjelaskan faktor-faktor yang melatarbelakangi perilaku Indonesia dalam kontribusinya pada kerja sama ASEAN terkait masalah di wilayah Segitiga Emas.

Selain memahami perilaku negara, artikel ini juga bertujuan memahami permasalahan domestik dan mencoba memberikan solusi terhadap permasalahan yang ada tersebut, sehingga simpulan artikel ini dapat memberikan kontribusi khususnya bagi pemerintah.

\section{Paradigma Liberalisme}

Liberalisme adalah sebuah filosofi politik yang secara umum berdasar pada ide-ide kebebasan (liberty) dan persamaan (equality) yang berakar pada pemikiran abad pencerahan (enlightment) yang percaya bahwa manusia adalah makhluk yang rasional. Liberalisme memiliki jangkauan yang luas, antara lain melihat peran pemerintah yang terbatas, 
rasionalitas, kebebasan individu, kebebasan politik (self determination), demokrasi, hak-hak yang dijamin oleh konstitusi, prinsip kesetaraan di muka hukum, kompetisi antar individu, dan kapitalisme pasar yang bertujuan untuk kemakmuran. Pemikiran Liberal dapat digunakan untuk mengkaji berbagai macam studi keilmuan, salah satunya dalam ilmu Hubungan Internasional (HI). Dalam ilmu HI, Liberalisme juga disebut Liberal Internasionalism karena mengadaptasi prinsip-prinsip politik liberal dalam manajemen sistem internasional (Brown \& Ainley, 2019).

Dalam pandangan Liberal, perang bukan merupakan keputusan individu, karena individu adalah makhluk rasional yang dapat memikirkan untung atau rugi yang akan menjadi dampak sebuah keputusan. Menurut Robert Jackson dan Georg Sorensen (Jackson \& Sorensen, 2013), kaum liberal meyakini bahwa prinsip-prinsip rasional dapat diaplikasikan pada hubungan internasional. Setiap individu secara rasional mementingkan diri sendiri dan bersikap kompetitif sampai dengan batasan tertentu. Kepentingan setiap individu akan bertemu melalui kerja sama dan kolaborasi. Kerja sama yang terjalin akan menghasilkan manfaat yang lebih besar bagi setiap individu yang terlibat. Meskipun terdapat perdebatan mengenai keberhasilan dan kegagalan serta besarnya hambatan dalam menjalin kerja sama, kaum liberal sepakat bahwa kerja sama demi kepentingan bersama akan berhasil dalam jangka panjang.

Mengutip pendapat John Locke (Jackson \& Sorensen, 2013:101) bahwa negara hadir untuk menjamin kebebasan warganya sehingga mereka dapat hidup tanpa campur tangan yang tidak semestinya dari orang lain. Apabila kaum realis melihat negara sebagai sebagai pusat dan instrumen utama kekuasaan, maka kaum liberalis melihat negara sebagai entitas konstitusional yang berupaya menegakkan supremasi hukum yang menghormati hakhak warga negara. Negara-negara konstitusional akan saling menghormati satu sama lain dan saling berhubungan berdasarkan norma toleransi yang disepakati bersama. Selanjutnya Jeremy Bentham berargumen bahwa terdapat kepentingan rasional negara-negara konstitusional untuk mematuhi hukum internasional dalam setiap kebijakan luar negerinya (Rosenblum 1978: 101 dalam Jackson dan Sorensen 2013:101).

\section{Liberalisme dalam ilmu HI} bersama-sama dengan Realisme dan Institusionalisme berada dalam kategori teori rasionalis. Yang membedakan yaitu 
Liberal menjelaskan kemungkinan kerja sama internasional yang tidak hanya dilakukan oleh negara, karena negara bukan satu-satunya aktor utama dalam hubungan internasional. Liberal secara luas melihat bahwa dunia juga terdiri dari aktor-aktor transnasional penting seperti Organisasi Internasional, Non-Governmental Organization (NGO), maupun individuindividu yang mampu melakukan kerja sama serta membentuk jaringan yang dapat melampaui batas-batas wilayah negara (Viotti \& Kauppi, 2012:129).

Secara garis besar, Liberalisme berasumsi mengenai anarki dan rasionalitas. Negara sebagai aktor yang berada dalam lingkungan politik internasional yang anarkis, tanpa adanya pemerintahan global atau otoritas yang memonopoli kekuasaan. Negara akan menerapkan konsep self-help. Secara rasional, pemimpin negara dan institusi domestik memiliki peran dalam membentuk kebijakan luar negeri yang bertujuan untuk mencapai kepentingan nasional dengan upaya dan biaya yang seefisien mungkin. Dalam perumusan kebijakan nasional, negara akan bertindak secara rasional dengan mempertimbangkan keuntungan dan kerugian yang mungkin akan didapatkan.
Menurut Moravcsik (Moravcsik, 1997:516), paradigma liberal menjelaskan tentang bagaimana sebuah negara mempunyai preferensi tertentu dalam menentukan perilakunya dalam dunia internasional. Premis fundamentalnya yaitu "the relationship between states and the surrounding domestic and transnational society in which they are embedded critically shapes state behavior by influencing the social purposes underlying state preference”. Hubungan antar negara serta hubungan antar masyarakat domestik dan transnasional di sekitar negara itu membentuk perilaku negara dengan cara mempengaruhi tujuan sosial yang mendasari preferensi negara. Teori liberal juga berasumsi bahwa kerja sama akan dilakukan ketika aktor merasa bahwa hal tersebut penting.

\section{Teori Republican Liberalism}

Di antara berbagai teori dalam paradigma liberal, Republican Liberalism merupakan sebuah teori yang memandang bahwa sumber utama preferensi negara adalah struktur politik domestik. Teori ini melihat bagaimana cara institusi-institusi dan praktik-praktik domestik memberikan tekanan serta mengubah tekanan tersebut menjadi kebijakan negara. Kebijakan suatu negara merupakan terjemahan dari kepentingan nasional. Teori Republican 
Liberalism menekankan peran institusi domestik, elit dan dinamika kepemimpinan serta hubungan antara legislatif-eksekutif.

Kebijakan negara cenderung menjadi bias dalam mendukung koalisi pemerintahan atau kelompok-kelompok domestik yang kuat dan didukung oleh lembaga-lembaga perwakilan, baik itu administrator (penguasa, militer, atau birokrasi) atau kelompok-kelompok masyarakat yang "menyandera" negara. Biaya dan risiko yang ditimbulkan oleh kebijakan akan dilemparkan ke pihak lain. Ketika kelompok-kelompok tertentu dengan preferensi asing mampu merumuskan kebijakan tanpa memberikan keuntungan bagi masyarakat secara keseluruhan, hasilnya kemungkinan akan menjadi kebijakan yang tidak efisien bagi kebijakan negara secara keseluruhan. Selama sebagian besar individu dan kelompok dalam masyarakat menolak risiko, dan semakin luas jangkauan kelompok yang diwakili, maka semakin kecil kemungkinan bahwa mereka akan mendukung penggunaan perang yang membebankan risiko dan biaya besar pada masyarakat. Sifat demokrasi yang cenderung selektif akan menentukan sikap dalam keterlibatan negara pada perang yang akan dimasuki, antara lain dengan cara: memilih perang yang berbiaya lebih rendah, tidak memprovokasi perang kekuatan besar, dan berjuang untuk menang.

\section{Dengan demikian, teori Republican} Liberalism juga membantu menjelaskan fenomena seperti "democratic peace", imperialisme modern, serta perdagangan internasional dan kerja sama moneter. Dengan beranggapan secara logis bahwa perang besar akan menimbulkan biaya yang harus ditanggung oleh masyarakat sebuah negara secara keseluruhan. Oleh karena itu, Republican Liberalism meyakini bahwa negara-negara yang menganut demokrasi liberal akan cenderung lebih damai. Teoriteori Liberal tidak terbatas hanya menjelaskan tentang kerja sama antar negara liberal, tetapi juga antara liberal dan non-liberal, antara situasi yang kooperatif ataupun konfliktual, isu-isu keamanan dan ekonomi politik, serta kebijakan luar negeri individu dan agregat perilaku (Moravcsik, 1997:533). Menurut Moravcsik, mekanisme kausal Teori Liberal dapat digunakan dalam berbagai isu.

Gambaran konseptualisasi Teori Republican Liberalisme berdasarkan analisis terhadap kerangka teori di atas tampak pada skema berikut: 


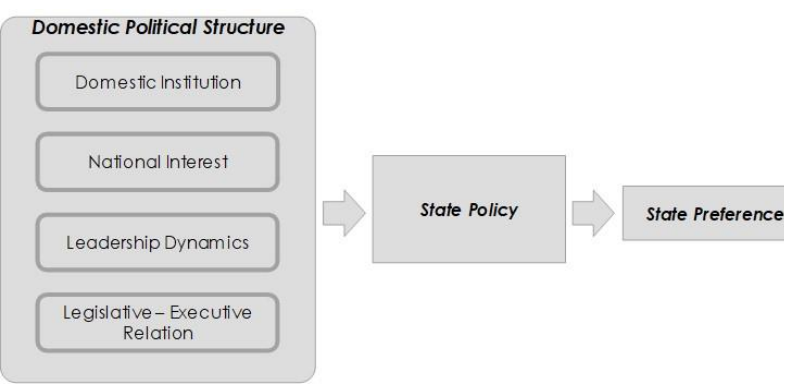

Gambar 3. Konseptualisasi Republican

\section{Liberalism}

\section{Metodologi Penelitian}

Pendekatan yang digunakan dalam penelitian ini yaitu metode kualitatif dan bersifat deskriptif. Berbagai sumber data digunakan dalam penelitian ini, antara lain data-data sekunder yang diperoleh dari artikel dan situs internet, lembaga pemerintah, dan institusi terkait. Sumber data yang diperoleh berbentuk dokumen, jurnal ilmiah, buku, laporan, dan catatan hasil pertemuan. Selain itu, pengumpulan data juga dilakukan dengan wawancara untuk memperoleh data primer yang dapat digunakan untuk memperkuat analisis. Wawancara dilakukan dengan pejabat terkait di Badan Narkotika Nasional (BNN) Republik Indonesia sebagai instansi yang menjadi focal point penanganan narkoba baik di level domestik dan regional. Datadata yang telah dikumpulkan kemudian dikelompokkan dan dianalisis secara kualitatif sehingga menghasilkan kesimpulan.

\section{Pembahasan}

Untuk memahami perilaku dan peran Indonesia dalam penanggulangan narkoba di wilayah Segitiga Emas sesuai dengan konseptualisasi di atas, maka perlu diketahui struktur politik domestik dan kebijakan negara yang membentuk preferensi Indonesia dalam menyikapi isu narkoba di kawasan Segitiga Emas.

Menurut paradigma Liberal, negara bukanlah unitary actor yang dapat menentukan perilakunya sendiri. Sikap dan perilaku negara di dunia internasional ditentukan oleh elemen-elemen yang berada di dalamnya. Menurut teori Republican Liberalism, elemen-elemen tersebut salah satunya yaitu struktur politik domestik yang terdiri dari variabel-variabel sebagai berikut:

\section{Institusi Dalam Negeri Indonesia}

Penanganan isu narkoba di Indonesia menggunakan pendekatan komprehensif terhadap masalah supply dan demand narkoba. Pendekatan ini secara teoretis merupakan kunci keberhasilan dalam menyelesaikan permasalahan narkoba. Institusi yang berperan antara lain BNN, Polri, Kementerian Kesehatan, Badan Pengawas Obat dan Makanan (BPOM), Bea Cukai, Kejaksaan, TNI, Imigrasi, dan PPATK. BNN sebagai focal point dan 
koordinator penanganan narkoba, bekerja sama dengan Polri dalam penyelidikan dan penyidikan serta operasi pemberantasan narkoba. Kementerian Kesehatan melalui Peraturan Menteri Kesehatan, serta BPOM selain juga berperan dalam penyidikan dan pengawasan, juga berperan dalam pengaturan narkotika, obat-obatan dan zatzat berbahaya. Bea dan Cukai berperan dalam penyelidikan dan pengawasan narkoba terutama di wilayah pelabuhan laut dan udara. Kejaksaan berperan dalam penuntutan kasus terkait peredaran gelap dan penyalahgunaan narkoba. Kementerian dan Lembaga tersebut terutama BNN menjadi variabel-variabel yang membentuk struktur politik domestik Indonesia.

Dalam penanganan narkoba di tingkat regional, Indonesia aktif dalam ASEAN Senior Officials on Drug Matters (ASOD) sebagai badan utama ASEAN yang menangani isu narkoba, serta mengimplementasikan ASEAN Work Plan on Securing Communities Against Illicit Drugs 2016-2025. Work Plan tersebut merupakan kerangka kerja yang menjadi pedoman negara-negara anggota ASEAN dalam menangani isu narkoba sekaligus menjadi instrumen dalam mengawasi kemajuan implementasinya. BNN juga terlibat dalam ASEAN Airport Interdiction Task Force (AAITF) dan ASEAN Seaport
Interdiction Task Force (ASITF) yang merupakan mekanisme kerja sama teknis negara anggota ASEAN dalam menangkal dan mencegah peredaran narkoba.

Keaktifan Indonesia terlihat dalam kehadiran delegasinya pada forum ASOD, AAITF, ASITF dan ASEAN Ministerial Meeting on Drug Matters (AMMD). Indonesia juga menjadi tuan rumah pertemuan-pertemuan tingkat ASEAN di bidang penanganan narkoba. Hasil-hasil yang diperoleh dalam keaktifan Indonesia dalam mekanisme kerja sama ASEAN menjadi faktor penting dalam perumusan dan penentuan kebijakan Indonesia dalam menangani isu narkoba.

Dalam lingkup bilateral, Indonesia juga menjalin kerja sama dalam melakukan pencegahan dan pemberantasan penyalahgunaan dan peredaran gelap narkoba dengan Laos, Myanmar dan Thailand yang merupakan tiga negara di kawasan Segitiga Emas. Kerja sama dituangkan dalam bentuk formal melalui Nota Kesepahaman antara BNN dengan Lao Commission on Drugs Control (LCDC), Central Committee for Drug Abuse Control (CCDAC) Myanmar dan Office of the Narcotics Control Board (ONCB) Thailand. Kerja sama secara teknis di antaranya penyediaan bantuan peningkatan kapasitas dalam bentuk 
pelatihan interdiksi terpadu yang diadakan oleh BNN yang mengikutsertakan penegak hukum dari LCDC dan CCDAC sebagai peserta.

\section{Kepentingan Nasional Indonesia}

Visi dan misi pemerintah Indonesia di era Presiden Joko Widodo diprioritaskan pada upaya menjaga kedaulatan Indonesia, meningkatkan perlindungan terhadap warga negara dan badan hukum Indonesia serta meningkatkan diplomasi ekonomi. Variabel kepentingan nasional Indonesia dalam konteks ini yaitu melindungi seluruh warga negara Indonesia dari ancaman penyalahgunaan dan peredaran gelap narkoba.

$$
\text { Upaya Indonesia dalam }
$$
menghadapi isu narkoba adalah dengan menetapkan strategi Supply Reduction dan Demand Reduction yang berimbang. Strategi Supply Reduction antara lain dengan pemberantasan peredaran gelap narkoba, penguatan interdiksi untuk menangkal penyelundupan narkoba, perampasan aset sindikat dan pengedar narkoba, serta pemberdayaan masyarakat yang salah satunya melalui program alternative development yang berupaya untuk mengalihkan budidaya tanaman ilegal menjadi tanaman produktif.

Di sisi lain, Demand Reduction diimplementasikan melalui upaya pencegahan penyalahgunaan narkoba, dan rehabilitasi. Bidang pencegahan menyasar pada kelompok-kelompok masyarakat yang rentan terhadap ancaman penyalahgunaan narkoba, antara lain kelompok usia produktif termasuk pelajar dan pekerja. Sedangkan bidang rehabilitasi berupaya memulihkan kecanduan bagi korban penyalahgunaan narkoba.

\section{Dinamika Kepemimpinan Indonesia}

Sikap Presiden Joko Widodo yang menanggapi isu narkoba dalam pidato dan pernyataannya bahwa Indonesia berada dalam kondisi "Darurat Narkoba". Presiden Joko Widodo juga menginstruksikan "perang melawan narkoba" dan "tembak di tempat" terhadap pengedar dan sindikat yang melakukan perlawanan. ${ }^{9}$ Di samping itu, penerapan hukuman mati sebagai hukuman maksimal yang diberlakukan bagi pengedar dan pelaku kejahatan narkoba juga menjadi gambaran urgensi kebijakan pemerintah terhadap isu narkoba. Kedua

9 Pernyataan Presiden Joko Widodo dalam pidatonya pada peringatan Hari Anti Narkotika Internasional 26 Juni 2016. 
hal tersebut menggambarkan seberapa serius ancaman narkoba bagi Indonesia.

\section{Hubungan Legislatif-Eksekutif Indonesia}

Dalam Undang-Undang No. 35 tahun 2009 tentang narkotika pasal 63 disebutkan bahwa Pemerintah berupaya untuk melakukan kerja sama internasional dengan aktor internasional baik secara bilateral maupun multilateral, dalam lingkup regional maupun internasional dalam penanganan Narkotika dan Prekursor Narkotika sesuai dengan kepentingan nasional.

Kerja sama telah menjadi salah satu instrumen utama dalam penanganan isu narkoba, tentunya dengan memperhatikan kepentingan nasional Indonesia. Selain itu, prioritas kebijakan luar negeri Indonesia yang aktif dalam melakukan mekanisme bilateral sebagai instrumen diplomatik juga menjadi arahan Presiden. Amanat UndangUndang tersebut diimplementasikan oleh lembaga Eksekutif yaitu Kementerian atau institusi terkait, terutama BNN sebagai leading sector, ke dalam rencana strategisnya yaitu menjalin kerja sama dengan negara-negara prioritas di kawasan, termasuk dengan negara-negara di sekitar Segitiga Emas.
Secara praktik, isu narkoba juga dibahas oleh legislatif di tingkat regional. Setiap tahun parlemen negara anggota ASEAN bertemu dalam ASEAN InterParliamentary Assembly Advisory Council on Dangerous Drugs (AIPACODD). Pertemuan ini merupakan lanjutan dari forum AIPA Fact-Finding Committee on Drug Menace (AIFOCOMM) sejak tahun 2002. Forum tersebut menjadi wadah pertukaran informasi, dan kerja sama antara Anggota Parlemen ASEAN dalam menangani ancaman narkoba di kawasan.

Baik legislatif dan eksekutif masing-masing bergerak secara parallel dalam kerja sama penanganan narkoba di tingkat regional. Akan tetapi, yang menjadi sorotan dalam variabel ini yaitu masih adanya ketimpangan informasi dan pemahaman antara legislatif dan eksekutif terhadap isu narkoba yang sangat kompleks.

$$
\text { Kurangnya sosialisasi dan }
$$
diseminasi informasi antar lembaga serta pemahaman lembaga selain BNN tentang situasi narkoba di tingkat regional terhadap situasi di tingkat nasional menjadi salah satu faktor terbatasnya perhatian terhadap besarnya pengaruh kawasan segitiga emas dalam peredaran narkoba di Indonesia. 


\section{Kesimpulan}

Adanya pandemi COVID-19 tidak mengurangi dampak dari aktivitas produksi dan peredaran narkoba ilegal di Segitiga Emas yang dirasakan di Indonesia. Langkah-langkah yang diperlukan sebagai adaptasi terhadap situasi terkini dalam penanganan narkoba di lingkup regional harus menjadi perhatian.

Secara rasional, akan lebih menguntungkan bagi Indonesia apabila mekanisme regional yang telah berjalan diperkuat dan dimanfaatkan secara lebih baik. Kesadaran kolektif kawasan harus ditingkatkan dengan adanya inisiatif kerja sama penanganan narkoba di masa pandemi.

Negara-negara yang bersinggungan dengan Segitiga Emas dan jalur sungai Mekong telah melakukan penanganan di level domestik, dan juga turut terlibat dalam mekanisme regional ASEAN. Indonesia mendukung mekanisme ASEAN sekaligus juga menjalin kerja sama bilateral dengan Myanmar, Laos, Thailand dan Viet Nam.

Tidak tampak upaya khusus yang dilakukan Indonesia untuk secara langsung melibatkan diri pada penanganan masalah segitiga emas. Akan tetapi, Indonesia secara normatif mendukung kerja sama terkait masalah di kawasan Segitiga Emas melalui mekanisme kerja sama regional. Hal ini dapat menjembatani antara peran negara dan efisiensi anggaran sebagai negara terdampak yang jauh dari Segitiga Emas.

Dengan berkontribusi pada SMCC misalnya, Indonesia secara rasional akan melihat keuntungan apa yang akan didapat. Dukungan Indonesia dapat memperkuat SMCC, sehingga meningkatkan efektivitas kinerjanya di kawasan. Keberhasilan tersebut tentunya akan membawa dampak positif seperti berkurangnya pasokan narkotiba ilegal yang diselundupkan ke Indonesia.

Akan tetapi, hal tersebut tidak bisa dipastikan, terlebih lagi kontribusi pada SMCC tentunya membutuhkan sumber daya baik manusia, peralatan dan anggaran yang tidak sedikit. Selain itu, mekanisme kerja sama bilateral dengan ketiga negara prioritas dinilai cukup menunjukkan peran Indonesia dan memberikan manfaat bagi negara-negara tersebut.

Di level domestik, sinergi antar lembaga sangat penting dalam menangani permasalahan narkoba ini. BNN sebagai institusi yang menjadi focal point dan penjuru penanganan narkoba harus lebih aktif dalam melakukan sosialisasi terkait narkoba termasuk sumber-sumber 
peredaran narkoba seperti kawasan segitiga emas. Penyediaan informasi yang lebih rinci bagi lembaga-lembaga yang juga terkait dalam penanganan narkoba harus ditingkatkan.

Dengan adanya pembatasan dan pengetatan perbatasan serta bandar udara di masa pandemi, laut menjadi jalur utama bagi peredaran narkoba. Di kawasan, ASEAN memiliki ASITF yang berperan dalam menangkal peredaran narkoba melalui jalur laut. Sedangkan bagi Indonesia, peningkatan keamanan maritim merupakan faktor terpenting karena menyadari Indonesia merupakan negara kepulauan.

Penulis adalah mahasiswa Pascasarjana Departemen Hubungan Internasional Universitas Indonesia. Penulis juga merupakan Analis Kerja Sama Regional pada Direktorat Kerja Sama, Deputi Bidang Hukum dan Kerja sama Badan Narkotika Nasional Republik Indonesia.

\section{Referensi}

Badan Narkotika Nasional. (2017). Jurnal Data Puslitdatin BNN: Hasil Survei Penyalahgunaan dan Peredaran Gelap Narkoba pada Kelompok
Pelajar dan Mahasiswa di 18 Provinsi Tahun 2016.

Badan Narkotika Nasional. (2018). Siaran Pers Akhir Tahun 2018.

Brown, C., \& Ainley, K. (2019). Understanding International Relations. In Palgrave Macmillan (5th ed.). https://doi.org/10.1057/978-1352-00423-6_1

Eligh, J. (2020). Crisis and Opportunity: Impacts of the coronavirus pandemic on illicit drug markets. May. www.globalinitiative.net

Giommoni, L. (2020). Why we should all be more careful in drawing conclusions about how COVID-19 is changing drug markets. International Journal of Drug Policy, 83, 102834. https://doi.org/10.1016/j.drugpo.2020. 102834

Gomis, B. (2020). How the Illicit Drug Trade Is Adapting to the Coronavirus Pandemic. World Politics Review, March.

https://www.worldpoliticsreview.com /articles/28696/how-the-illicit-drugtrade-is-adapting-to-the-coronaviruspandemic

Jackson, R., \& Sorensen, G. (2013). Introduction to International Relations 
Theory and Approaches. In Oxford University Press (5th ed.). Oxford University Press.

Kanato, M., Leyatikul, P., \& Choomwattana, C. (2018). ASEAN Drug Monitoring Report 2017. In ASEAN Narcotics Cooperation Center. https://asean.org/wpcontent/uploads/2016/10/Doc6-

ADM-Report-2016-as-of-15-

November-2017-FINAL.pdf

Kementrian Kesehatan RI. (2017).

Infodatin Narkoba 2017 Kementrian

Kesehatan Republik Indonesia.

Lijun, S. (2006). CHINA-ASEAN COOPERATION AGAINST ILLICIT DRUGS FROM THE GOLDEN TRIANGLE Author ( $s$ ): Sheng Lijun Published by: Lynne Rienner Publishers Stable URL: http://www.jstor.org/stable/42704545 . 30(2), 97-126.

Moravcsik, A. (1997). Taking Preferences Seriously: A Liberal Theory of International Politics. International Organization, 51(4), 513-553. https://doi.org/10.1162/00208189755 0447

Sudirman, M. R. dan A. (2020). Signifikansi Keamanan Maritim Di
ASEAN. Jurnal: Mandala, Vol 3 No 2, 167.

https://ejournal.upnvj.ac.id/index.php/ JM/article/download/2174/1018

UN. (2015). World Drug Report 2015 (Vol. 2015).

UNODC. (2021). World Drug Report 2021. Booklet 5. COVID-19 and Drugs: Impact Outlook.

Viotti, P. R., \& Kauppi, M. V. (2012). International Relations Theory (5th ed.). Longman. 